\title{
Novel applications of platelet concentrates in tissue regeneration (Review)
}

\author{
ZHEN-YU DING ${ }^{1}$, YING TAN ${ }^{2}$, QIAN PENG $^{1}$, JUN ZUO $^{1}$ and NING $\mathrm{LI}^{2}$ \\ ${ }^{1}$ Hunan Key Laboratory of Oral Health Research, Hunan 3D Printing Engineering Research Center of Oral Care, \\ Hunan Clinical Research Center of Oral Major Diseases and Oral Health, Xiangya Stomatological Hospital, \\ Xiangya School of Stomatology, Central South University; ${ }^{2}$ Department of Blood Transfusion, Xiangya Hospital, \\ Clinical Transfusion Research Center, Central South University, Changsha, Hunan 410008, P.R. China
}

Received July 30, 2020; Accepted December 3, 2020

DOI: $10.3892 /$ etm.2021.9657

\begin{abstract}
Numerous studies have explored the suitability of biocompatible materials in regenerative medicine. Platelet concentrates are derived from centrifuged blood and are named according to their biological characteristics, such as plateletrich plasma, platelet-rich fibrin and concentrated growth factor. Platelet concentrates have gained considerable attention in soft and hard tissue engineering. Indeed, multiple components of autologous platelet concentrates, such as growth factors, fibrin matrix and platelets, serve essential roles in wound healing. Current studies are focused on cutting-edge strategies to meet the requirements for tissue restoration by improving the properties of autologous platelet concentrates. In the present review, applications of platelet concentrates for tissue engineering are discussed, presenting a selection of recent advances and novel protocols. In addition, several aspects of these strategies, such as the advantages of lyophilized platelet concentrates and the combination of platelet concentrates with biomaterials, stem cells or drugs are discussed. The present review aims to summarize novel strategies using platelet concentrates to improve the outcomes of wound healing.
\end{abstract}

Correspondence to: Professor Ning Li, Department of Blood Transfusion, Xiangya Hospital, Clinical Transfusion Research Center, Central South University, 87 Xiangya Road, Changsha, Hunan 410008, P.R. China

E-mail: Liningxy@csu.edu.cn

Professor Jun Zuo, Hunan Key Laboratory of Oral Health Research, Hunan 3D Printing Engineering Research Center of Oral Care, Hunan Clinical Research Center of Oral Major Diseases and Oral Health, Xiangya Stomatological Hospital, Xiangya School of Stomatology, Central South University, 72 Xiangya Road, Changsha, Hunan 410008, P.R. China

E-mail: zuojunxykq@163.com

Key words: platelet concentrates, platelet-rich fibrin, wound healing, tissue regeneration, growth factors

\section{Contents}

1. Introduction

2. Methods

3. Classification and preparation of platelet concentrates

4. Rationale of platelet concentrates in tissue restoration

5. Strategies to enhance the properties of platelet concentrates for clinical applications

6. Conclusions

\section{Introduction}

Regenerative medicine and tissue engineering aim to restore both the structure and functions of damaged tissues (1). In recent years, novel and more efficient regenerative strategies have been devised. These emerging approaches employ specific biocompatible and bioactive composite or natural scaffolds, into which cells or bioactive molecules are incorporated to construct a dynamic environment for wound healing in damaged tissues (2). However, the development and optimization of low-cost and effective therapeutic methods remains the primary goal (3).

Several studies have focused on autologous platelet concentrate derivatives, which may delay complications and boost tissue regeneration. It has been $>40$ years since the first generation of autologous platelet concentrates, termed plateletrich plasma (PRP), was produced (4). Since then, other platelet concentrates have been established, including platelet-rich fibrin (PRF) and concentrated growth factor (CGF). Platelet concentrates have three standard characteristics: i) They act as scaffolds, ii) they serve as a source of GF and iii) they contain live cells (Fig. 1 describes the rationale of using platelet concentrates in tissue regeneration) (5). These characteristics make platelet concentrates suitable candidates for tissue regeneration in clinical practice. The clinical applications of these types of derivatives of platelet concentrates in sports, spine and musculoskeletal medicine, ophthalmology and oral surgery have increased over the past few decades, resulting in positive clinical effects due to their ability to rapidly regenerate tendon, muscle and bone cartilage and speed up wound healing (6). Platelet concentrate injections in the knee for curing early osteoarthritis have achieved satisfying clinical results $(7,8)$. 
Platelet concentrates may serve as filling material for postextraction alveolar sockets, resulting in increased bone quality and soft-tissue healing $(9,10)$. In addition, dormant corneal ulcers associated with surgery may be healed by platelet concentrates prospectively (11). Chronic ulcers, characterized by a prolonged, self-perpetuating inflammatory phase, slow and defective formation of extracellular matrix and a decreased rate or a failure of re-epithelialization are general complications associated with diabetes or bedsores (12-17). Platelet concentrates provide a novel standard of chronic wound care and achieve satisfying healing effects in the clinic. These positive results suggest that platelet concentrates may be used to effectively manage simple clinical issues.

However, the single use of platelet concentrates may not always provide satisfactory clinical results, particularly as complex clinical issues are concerned, such as substantial wounds accompanied with infection, where the high demands of wound healing result in a high degree of tissue tension. Occasionally, the goal is to restore tissues rapidly with improved healing results, such as in skin and cartilage, with the restored tissue being similar to the normal tissue, thus making it functionally better or compared with the simple use of platelet concentrates. In addition, prolonged degradation of platelet concentrates is required to keep pace with the slow regeneration of bones. Thus, it is necessary to develop platelet concentrates further, such that they are suitable for use in complex clinical applications and meet regenerative expectations. The present review highlights novel strategies utilizing platelet concentrates for tissue engineering and discusses several aspects of these strategies, such as lyophilized platelet concentrates, as well as the combination of platelet concentrates with biomaterials, stem cells or medications. The aim of the present review is to discuss the current progress in the field and highlight potential avenues for development strategies utilizing platelet concentrates with improved quality and performance for different therapeutic applications. Therefore, a comprehensive and detailed review on modifying strategies of platelet concentrates in various types of tissue regeneration is provided. An overview is presented in Fig. 2.

\section{Methods}

This detailed review focuses on research employing platelet concentrates for novel tissue engineering applications. A comprehensive literature search was performed to identify appropriate studies for inclusion, incorporating several databases (Fig. 3) and using permutations of multiple search terms as follows: Platelet Rich Plasma; PRP; Platelet Rich fibrin; Platelet Rich Fibrin; PRF; Platelet-Rich Fibrin; Leukocyte Platelet Rich Fibrin; Leukocyte Platelet-Rich Fibrin; LPRF; L-PRF; Advanced Platelet Rich Fibrin; Advanced PRF; A-PRF; APRF; Injectable Platelet Rich Fibrin; IPRF; Concentrated Growth Factors; CGF and Soft Tissue Regeneration; Soft Tissue Wound Regeneration; Soft Tissue Wound-Healing; Wound Healing; Bone Regeneration; Bone Formation; Tissue Engineering. The inclusion criteria comprised studies published in the English language and both in vitro and in vivo evaluations of novel tissue regeneration applications of platelet concentrates. Methods, objectives, conclusions, potential future directions and potential shortcomings of included studies were reviewed.

\section{Classification and preparation of platelet concentrates}

Platelet concentrates may be defined as autologous biological products obtained following centrifugation of peripheral blood. Different centrifugal speeds result in various types of platelet concentrates and the characteristics are compared and summarized in Table I. PRP was introduced in the 1970s and is recognized as the first generation of platelet concentrates (4). PRP is produced by a two-step procedure: Blood is collected and centrifuged at high speeds after the addition of an anticoagulant. The plasma, erythrocytes and buffy coat separate at the top, bottom, and in the middle layer, respectively. The buffy coat contains platelets and leukocytes. Blood cells are removed and the remnants are centrifuged at a higher speed. Finally, PRP is collected from the bottom layer. To obtain insoluble PRP, bovine serum or $2 \%$ of calcium chloride are added. This process converts plasmatic fibrinogen into insoluble fibrin scaffolds and activates the platelets (18-20). However, the primary concern with this procedure is the presence of chemical or biological additives that may have adverse effects on tissue regeneration and delay wound healing.

Consequently, in 2001, the optimization of the preparation protocol was introduced by Choukroun, a second generation of platelet concentrates called PRF, which was subsequently renamed as leukocyte PRF (L-PRF), an enhanced version of PRP $(21,22)$. PRF has three primary advantages: i) Chemical or biological additives are absent, which avoids their related adverse reactions; ii) fibrin clots are naturally formed, so there is no requirement to add platelet activators, such as bovine serum or calcium chloride; iii) a higher concentration of host immune cells is collected in the fibrin matrix $(3,23)$. Since lowspeed centrifugation preserves more immune cells, GF and cytokines (24), this procedure has gained popularity, resulting in the production of advanced PRF (A-PRF) and injectable PRF (i-PRF). In a standard protocol, PRF is centrifuged at $708 \mathrm{x}$ g for $12 \mathrm{~min}$, whereas A-PRF is processed at $208 \mathrm{x} \mathrm{g}$ for $8 \mathrm{~min}(25)$ and i-PRF is centrifuged at $60 \mathrm{x} \mathrm{g}$ for $3 \mathrm{~min}(26)$. Another advantage of i-PRF is that it produces a solid fibrin clot within $15 \mathrm{~min}$, which gives operators adequate time to handle it and combine with other materials.

CGF is considered the third generation of autologous plasma and is prepared by a different centrifugation method. These platelet concentrates are produced by centrifuging blood samples at dynamic speeds, which increases the density of the fibrin matrix and the concentration of GF (27). However, it is not easy to differentiate A-PRF and CGF either macroscopically or microscopically due to their similar principles of preparation and they are thus classified as the same type of platelet concentrate (Table I) (28).

\section{Rationale of using platelet concentrates in tissue restora- tion}

The wound-healing process consists of five stages: Hemostasis, inflammation, cell proliferation, migration and tissue remodeling/maturation (29,30). Platelets, GF, leukocytes and fibrous proteins serve essential roles in these phases. The aim of the present review is not to describe their functions in detail. The respective functions of the primary ingredients 


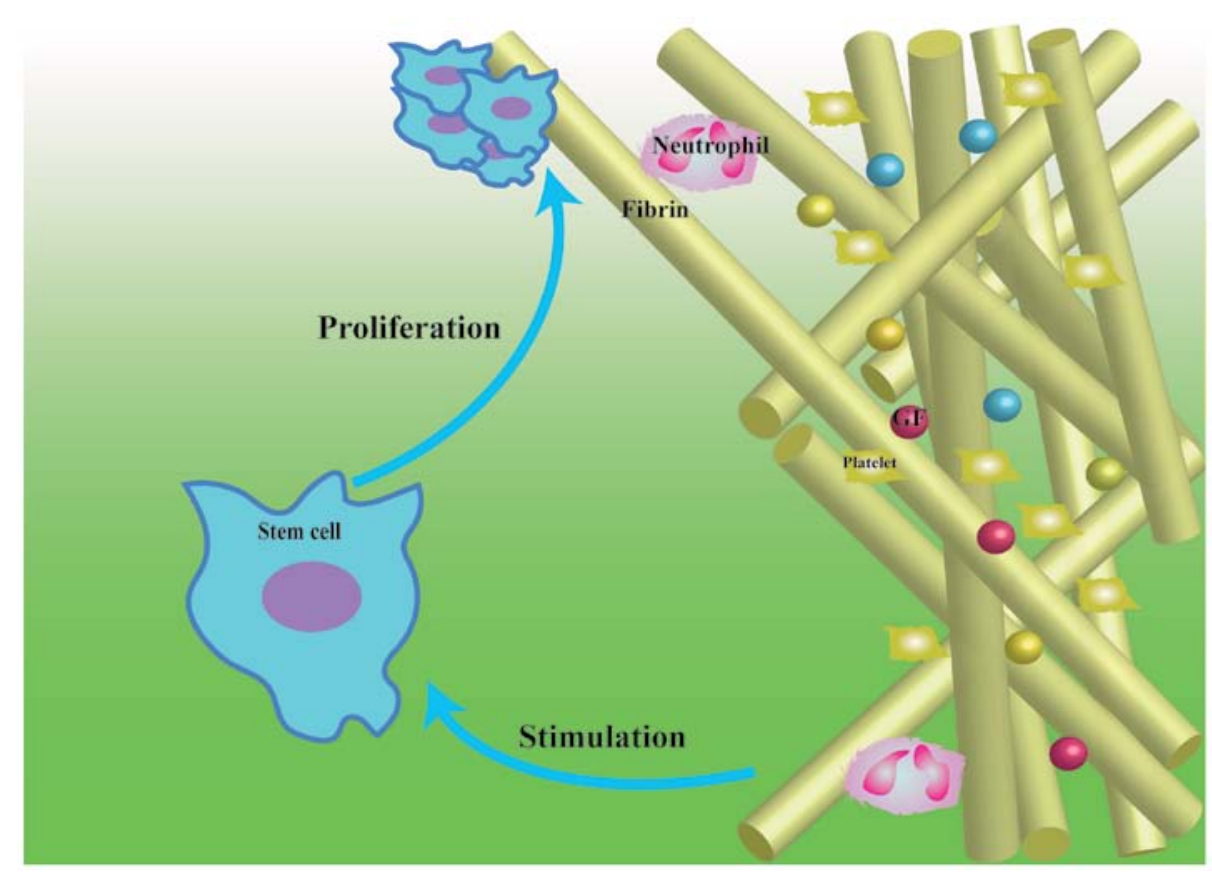

Figure 1. Schematic of the rationale of using platelet concentrates in tissue regeneration. GF, growth factor.

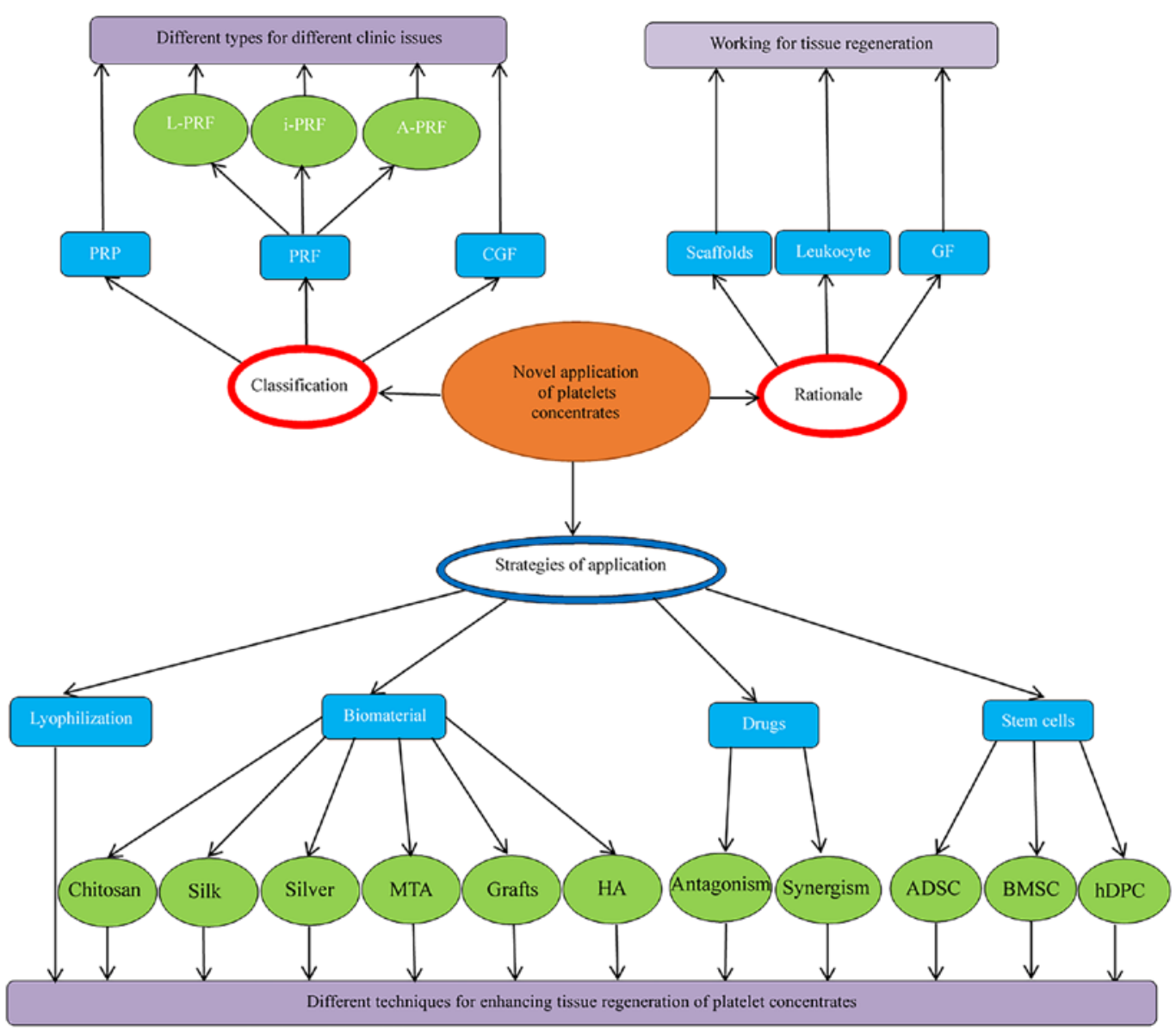

Figure 2. Platelet concentrates and application strategies. PRP, platelet-rich plasma; i-PRF, injectable platelet-rich fibrin; GF, growth factor; BMSC, bone marrow stromal cells; A-PRF, advanced PRF; HA, hydroxyapatite; L-PRF, leukocyte PRF; CGF, concentrated GFs; ADSC, adipose-derived stem cell; h-DPC, human dental pulp cells; MTA, mineral trioxide aggregate.

of platelet concentrates in the wound-healing process may be generally summarized as stated below.
GF serve critical roles in wound healing. These cytokines originate from cells, including platelets and leukocytes, or 
Table I. Comparison of characteristics of platelet concentrates.

\begin{tabular}{|c|c|c|c|c|c|c|}
\hline \multirow{2}{*}{$\begin{array}{l}\text { Classification/ } \\
\text { author (year) }\end{array}$} & \multirow{2}{*}{$\begin{array}{l}\text { Platelet-rich } \\
\text { plasma }\end{array}$} & \multicolumn{3}{|c|}{ PRF } & \multirow{2}{*}{$\begin{array}{l}\text { Concentrated } \\
\text { growth factors }\end{array}$} & \multirow[b]{2}{*}{ Ref. } \\
\hline & & L-PRF & i-PRF & A-PRF & & \\
\hline \multicolumn{7}{|l|}{ Anticoagulants } \\
\hline $\begin{array}{l}\text { Miron et al (2017) } \\
\text { Isobe (2017) }\end{array}$ & Yes & No & No & No & No & $\begin{array}{l}(26) \\
(86)\end{array}$ \\
\hline \multicolumn{7}{|l|}{$\begin{array}{l}\text { Preparation }(\mathrm{RCF} / \mathrm{g}) \\
\text { centrifuge tube }\end{array}$} \\
\hline $\begin{array}{l}\text { Hatakeyama et al (2014) } \\
\text { Miron et al (2017) } \\
\text { Pitzurra et al (2020) }\end{array}$ & $\begin{array}{l}700 / 8+1600 / 8 \\
\text { (plastic tubes) }\end{array}$ & $\begin{array}{l}708 / 12 \\
\text { (glass tubes) }\end{array}$ & $\begin{array}{l}60 / 3 \\
\text { (plastic tubes) }\end{array}$ & $\begin{array}{l}208 / 8 \\
\text { (glass tubes) }\end{array}$ & $\begin{array}{l}\text { Altered speed } \\
\text { (glass tubes) }\end{array}$ & $\begin{array}{l}(19) \\
(26) \\
(25)\end{array}$ \\
\hline \multicolumn{7}{|l|}{ Contents } \\
\hline $\begin{array}{l}\text { Miron et al (2017) } \\
\text { Masuki (2016) }\end{array}$ & $\begin{array}{l}\text { Leukocytes, GF } \\
\text { and fibrinogen }\end{array}$ & $\begin{array}{l}\text { Leukocytes, } \\
\text { GF and fibrin }\end{array}$ & $\begin{array}{l}\text { Leukocytes, GF } \\
\text { and fibrinogen }\end{array}$ & $\begin{array}{l}\text { Leukocytes, } \\
\text { GF and fibrin }\end{array}$ & $\begin{array}{l}\text { Leukocytes, } \\
\text { GF and fibrin }\end{array}$ & $\begin{array}{l}(5) \\
(87)\end{array}$ \\
\hline \multicolumn{7}{|l|}{$\begin{array}{l}\text { Morphological } \\
\text { characteristics }\end{array}$} \\
\hline $\begin{array}{l}\text { Miron et al (2018) } \\
\text { Isobe (2017) }\end{array}$ & Liquid & Solid & Liquid & Solid & Solid & $\begin{array}{l}(3) \\
(86)\end{array}$ \\
\hline \multicolumn{7}{|l|}{ Fibrin formation } \\
\hline $\begin{array}{l}\text { Miron and Zhang (2018) } \\
\text { Hatakeyama et al (2014) } \\
\text { Anitua et al (2019) } \\
\text { Ghanaati et al (2014) } \\
\text { Malli et al (2019) }\end{array}$ & $\begin{array}{l}\text { Requirement } \\
\text { to be induced }\end{array}$ & Natural & $\begin{array}{l}\text { Delayed } \\
\text { formation }\end{array}$ & Natural & Natural & $\begin{array}{l}(3) \\
(19) \\
(20) \\
(23) \\
(27)\end{array}$ \\
\hline $\begin{array}{l}\text { Fibrin density } \\
\text { Masuki (2016) } \\
\text { Isobe (2017) }\end{array}$ & - & + & - & ++ & ++ & $\begin{array}{l}(87) \\
(86)\end{array}$ \\
\hline \multicolumn{7}{|l|}{ Degradable rates } \\
\hline
\end{tabular}

L-PRF, leukocyte platelet-rich fibrin; i-PRF, injectable PRF; A-PRF, advanced PRF; GF, growth factor; -, none; +, medium amount; ++, large amount.

plasma. In general, GF stimulates the proliferation of stem cells (Fig. 1). These factors include platelet-derived growth factor (PDGF), vascular endothelial growth factor (VEGF), basic fibroblast growth factor (bFGF) and transforming growth factor- $\beta$ (TGF- $\beta$ ) (31,32). They serve different roles in different phases of the wound-healing process. The function of PDGF may be summarized as follows: First, it initiates and drives the wound-healing process by guiding neutrophils, macrophages and fibroblasts into the wound site from the early stage; subsequently, it activates macrophages and other cells possessing the potential for differentiation, such as fibroblasts, thereby resulting in provisional extracellular matrix synthesis, stem cell proliferation and collagen synthesis; finally, it triggers remodeling of the wound by activating and cross-linking collagen (33). Angiogenesis is a part of the tissue remodeling/maturation phase in wound healing. In this phase, both bFGF and VEGF promote endothelial cells to migrate and proliferate and differentiate into new blood vessels. Furthermore, TGF- $\beta$ may promote angiogenesis, collagen synthesis and collagenase secretion and modulate osteoblastic cell division (31).

During the synthesis of autologous fibrin scaffolds, the 3-dimensional fibrin nano-scaffold incorporates the platelets in a non-diffusible mode and binds platelet- and plasma-derived
GF before they attach to their corresponding cell-surface receptors (20). As the fibrin matrix is gradually degraded, GF and platelets are slowly released into the injured site at a rate consistent with that required for tissue growth $(34,35)$. Furthermore, the fibrin matrix provides mechanical support, plastic-elastic stiffness and space for cellular migration and proliferation (Fig. 1) (36,37). Thus, platelet concentrates fulfill different requirements for tissue restoration by linking molecular and cellular events.

\section{Strategies to enhance the properties of platelet concen- trates for clinical applications}

General. The tissue regeneration process involves cells, signaling biomolecules and scaffolding. The reparative protocols introduced in the present review focus on the application of platelet concentrates in several forms, either lyophilized or blended with (bio)materials (chitosan, silk fibrin, metal nanoparticles, mineral trioxide aggregate graft materials and hydroxyapatite) and/or stem cells [adipose-derived stem cells, bone marrow stromal cells (BMSC) and human dental pulp cells] or those modulated with drugs (antagonism and synergism) to enhance tissue regeneration. An overview is provided in Table II. 


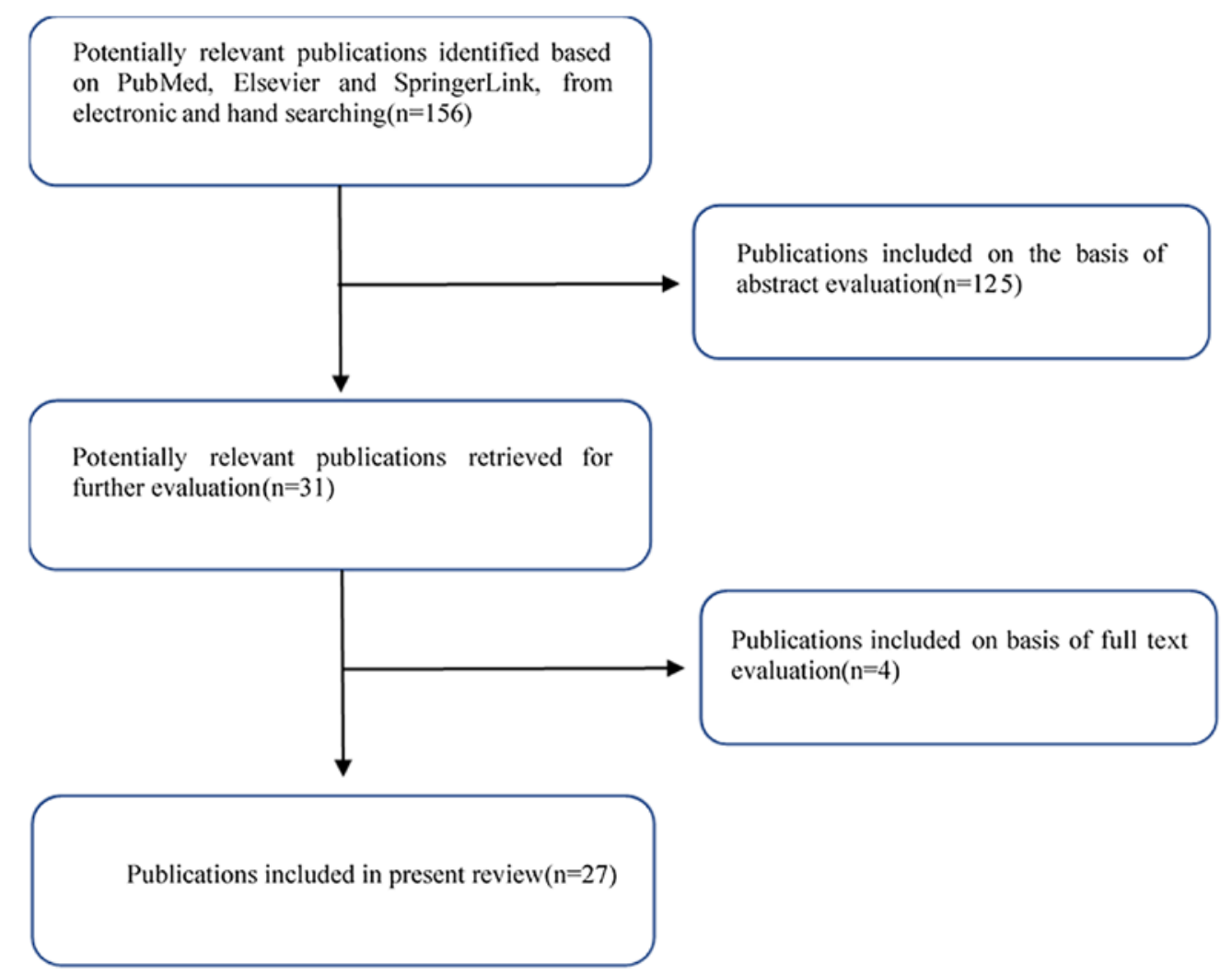

Figure 3. Flow chart of the screening process for the identification and inclusion of relevant publications.

Lyophilized platelet concentrates. Lyophilization, a process comprising sublimation and desorption of water from the frozen sample, may improve protein stability, extend shelflife and preserve the biological activity of samples (38-41). Therefore, although it is not necessary to use platelet concentrates after lyophilization immediately, there may be concerns regarding whether lyophilization affects the restorative abilities of platelet concentrates. Based on the current body of knowledge, it is not easy to differentiate between the number of GF between lyophilized and fresh PRF. Furthermore, during the process of lyophilization, the structure of the fibrin matrix is altered substantially. For instance, the pore size of the fibrin matrix is enlarged, which accelerates its degradation rate. The process of lyophilization may also damage the structure of leukocytes and this may reduce immunological rejection. Since the amount of GF in lyophilized and fresh platelet concentrates retains consistency, the in vitro osteogenic capacity of BMSC sheets treated with fresh or lyophilized platelet concentrates is unaffected (41). Owing to the changes in the structure of lyophilized platelet concentrates, adhesion and migration of stem cells in vivo may in turn be affected, which may improve bone regeneration in bone defects compared with the fresh preparations (42). However, results regarding lyophilized PRF are inconsistent. For instance, one study reported that lyophilized PRF appears to retain an architecture similar to that of fresh PRF (both lyophilized and fresh PRF exhibit an abundance of leukocytes with nuclei distributed within the fibrin matrix) (43). However, the sponge structure of lyophilized PRF has a larger internal space than that of fresh PRF, while the structure of fibrin is similar in both types of PRF. The conclusion derived from this contrasting scenario is that lyophilization of PRF may preserve its bioactivity in tissue regeneration. On the other hand, another concern is whether mixing lyophilized and fresh PRF at different ratios is better than the use of lyophilized or fresh PRF alone. Studies have indicated that mixing lyophilized and fresh PRF at a 1:1 ratio may exert improved healing effects in vivo, as TGF- $\beta$ was released more steadily, which confirmed the hypothesis that fresh/lyophilized PRF not only prolongs the release of GF but also delays the peak of release (44).

We hypothesized that lyophilization may not influence cell sheets in vitro due to the constant levels of GF in lyophilized and fresh PRF preparations. However, structural changes occur due to lyophilization, such as enlarged pore size, which serve pivotal roles in wound healing and influence proliferation, adhesion and migration of stem cells in vivo. Consequently, further investigations are required to verify whether lyophilized PRF exhibits increased tissue-restorative capacities compared with fresh PRF.

Platelet concentrates combined with biomaterials. Biomaterials are widely used in tissue engineering for their unique biological characteristics, which may be used to cover the shortcomings of platelet concentrates. Potential shortcomings of platelet concentrates include the possibility that released cytokines may not sustain tissue regeneration for a prolonged period and that platelet membranes may be vulnerable to mechanical stress $(4,30,45)$, limiting their surgical applicability. Therefore, the following section addresses several approaches that have been proposed to overcome this problem.

Chitosan. Chitosan contributes to several phases of wound repair via the promotion of cellular organization (46). This 
Table II. Studies evaluating the effects of strategies/advanced techniques of platelet concentrates in tissue regeneration.

\begin{tabular}{|c|c|c|c|c|}
\hline \multicolumn{5}{|l|}{ A, Lyophilization } \\
\hline Author (year) & Setting & Research direction & Conclusion & Ref. \\
\hline Wang et al (2019) & $\begin{array}{l}\text { In vivo and } \\
\text { in vitro }\end{array}$ & Bone and osteoblasts & $\begin{array}{l}\text { LPRF promotes BMSC proliferation and osteogenic } \\
\text { differentiation; bone regeneration with LPRF } \\
\text { and BMSC in mice. }\end{array}$ & (41) \\
\hline $\mathrm{Li}(2014)$ & $\begin{array}{l}\text { In vivo and } \\
\text { in vitro }\end{array}$ & Bone and MSC & $\begin{array}{l}\text { Lyophilization favors PRF promotes Runx } 2 \text {-mediated } \\
\text { osteogenic lineage commitment in alveolar bone } \\
\text { cells in alveolar bone cells mainly; } \\
\text { bone regeneration and mineralization. }\end{array}$ & (42) \\
\hline Liu et al (2019) & $\begin{array}{l}\text { In vivo and } \\
\text { in vitro }\end{array}$ & Bone and BMSC & $\begin{array}{l}\text { Combination of fresh and lyophilized PRF favors BMSC } \\
\text { osteogenic differentiation in vitro and bone } \\
\text { formation in vivo. }\end{array}$ & (44) \\
\hline Zhang et al (2017) & In vivo & Bone & $\begin{array}{l}\text { Lyophilization preserves the clinical effects. } \\
\text { of PRF with tissue healing }\end{array}$ & (43) \\
\hline
\end{tabular}

B, Combination with (bio)materials

\begin{tabular}{|c|c|c|c|}
\hline Method/author (year) & Setting & Research direction & Conclusion \\
\hline \multicolumn{4}{|l|}{ Chitosan } \\
\hline Mohammadi et al (2016) & In vivo & $\begin{array}{l}\text { Full-thickness } \\
\text { wound healing }\end{array}$ & $\begin{array}{l}\text { Chitosan and PRP combinations promote wound healing } \\
\text { by promoting collagen synthesis. }\end{array}$ \\
\hline Shimojo et al (2016) & In vitro & Human ADMSCs & $\begin{array}{l}\text { Composite scaffolds control the release of and enhance } \\
\text { the proliferation of ADMSCs. }\end{array}$ \\
\hline Wang et al (2019) & In vitro & Murine-derived cell & $\begin{array}{l}\text { CGF loaded on chitosan-alginate stably releases GF and } \\
\text { presents superior osteogenic effects. }\end{array}$ \\
\hline Ansarizadeh et al (2019) & In vitro & Bone marrow MSCs & $\begin{array}{l}\text { Composite scaffolds present higher Young's modulus and } \\
\text { MSC viability and lower degradation rate. }\end{array}$ \\
\hline \multicolumn{4}{|l|}{ Silk fibrin } \\
\hline Lee et al (2010) & In vivo & Bone & $\begin{array}{l}\text { A combination of PRF and silk fibroin presented faster } \\
\text { bone formation than the unfilled group. }\end{array}$ \\
\hline \multicolumn{4}{|l|}{ SNPs } \\
\hline Khorshidi et al (2018) & In vitro & $\begin{array}{l}\text { Antimicrobial } \\
\text { properties }\end{array}$ & $\begin{array}{l}\text { Modification of L-PRF by SNPs exhibits antimicrobial } \\
\text { properties, mainly for viridans streptococci and } \\
\text { higher mechanical strength. }\end{array}$ \\
\hline \multicolumn{4}{|l|}{ MTA } \\
\hline Woo et al (2018) & In vitro & h-DPCs & $\begin{array}{l}\text { The synergic effects of MTA and PRF promote the } \\
\text { differentiation of h-DPCs into odontoblast-like cells } \\
\text { through the activation of BMP/Smad signaling pathway. }\end{array}$ \\
\hline \multicolumn{4}{|l|}{ Graft materials } \\
\hline Abdullah (2016) & In vivo & Bone & $\begin{array}{l}\text { A combination of } \mathrm{PRF} \text { and } \beta-\mathrm{TCP} \text { accelerates bone } \\
\text { regeneration compared to } \mathrm{PRF} \text { alone. }\end{array}$ \\
\hline Karayurek et al (2019) & In vivo & Bone & $\begin{array}{l}\text { A combination of PRF and autograft presents superior } \\
\text { bone regeneration than other graft materials. }\end{array}$ \\
\hline \multicolumn{4}{|r|}{ 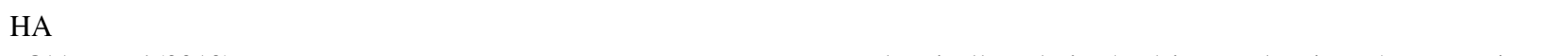 } \\
\hline Ohba et al (2012) & In vivo & Bone & $\begin{array}{l}\text { Electrically polarized HA/PRP gel activated osteogenic } \\
\text { cells to enhance bone regeneration. }\end{array}$ \\
\hline Sadeghinia et al (2019) & In vitro & h-DPSCs & $\begin{array}{l}\text { PRP-fibrin glue/chitosan-gelatin/nano HA provides rich GF } \\
\text { to promote differentiation and proliferation of h-DPSCs. }\end{array}$ \\
\hline
\end{tabular}

C, Combination with stem cells

\begin{tabular}{llll}
\hline Method/author (year) & Setting & Research direction & Conclusion \\
\hline ADSC
\end{tabular}

ADSC

$\begin{array}{lll}\text { Stessuk et al (2016) In vitro } & \begin{array}{l}\text { Fibroblasts and } \\ \text { keratinocytes }\end{array}\end{array}$

A combination of ADSC and PRP stimulates fibroblasts and keratinocytes to proliferate. 
Table II. Continued.

C, Combination with stem cells

\begin{tabular}{|c|c|c|c|c|}
\hline Method/author (year) & Setting & Research direction & Conclusion & Ref. \\
\hline Chen et al (2014) & In vitro & $\begin{array}{l}\text { Maxillofacial } \\
\text { soft tissue }\end{array}$ & $\begin{array}{l}\text { A mixture of PRF and ADSC cures injury of maxillofacial } \\
\text { soft tissue by irradiation better than PRF or ADSC alone. }\end{array}$ & (70) \\
\hline Sun et al (2014) & In vivo & Myocardial tissue & PRF-embedded autologous ADMSC protects left ventricle. & (71) \\
\hline \multicolumn{5}{|c|}{ Bone mesenchymal cells } \\
\hline Park et al (2017) & In vivo & Bone & Increased bone formation. & (68) \\
\hline Wang et al (2017) & In vivo & Bone & $\begin{array}{l}\text { The combined application of an MSC sheet with nano-HA } \\
\text { and granular PRF promotes bone regeneration } \\
\text { in large bone defects. }\end{array}$ & (72) \\
\hline Wang et al (2016) & $\begin{array}{l}\text { In vivo and } \\
\text { in vitro }\end{array}$ & $\begin{array}{l}\text { Periodontal ligament } \\
\text { and jaw bone MSC }\end{array}$ & $\begin{array}{l}\text { Periodontal ligament stem cells/PRF/jaw bone MSCs } \\
\text { induce periodontal ligament- and bone-like tissue. }\end{array}$ & (73) \\
\hline Wu et al (2017) & In vivo & Bone & $\begin{array}{l}\text { MSC + PRF releasate induce hyaline-like cartilage in defects } \\
\text { and present better results than PRF or MSC alone. }\end{array}$ & (74) \\
\hline \multicolumn{5}{|l|}{ h-DPC } \\
\hline He et al (2016) & In vitro & h-DPC & $\begin{array}{l}\text { When h-DPC is added before blood centrifugation during } \\
\text { the preparation of PRF, the PRF-h-DPC complex } \\
\text { is successfully developed. }\end{array}$ & $(75)$ \\
\hline
\end{tabular}

$\mathrm{D}$, Combination with drugs

\begin{tabular}{|c|c|c|c|c|}
\hline Method/author (year) & Setting & Research direction & Conclusion & Ref. \\
\hline \multicolumn{5}{|l|}{ Antagonism } \\
\hline Steller et al (2019) & In vitro & Osteoblasts & $\begin{array}{l}\text { PRF and PRP enhance bone healing in patients with } \\
\text { osteonecrosis of the jaw and PRF is better than PRP. }\end{array}$ & (81) \\
\hline Borsani et al (2018) & In vitro & Osteoblasts & $\begin{array}{l}\text { Cotreatment with resveratrol and CGF protect } \\
\text { osteoblasts treated with bisphosphonates. }\end{array}$ & (83) \\
\hline \multicolumn{5}{|l|}{ Synergism } \\
\hline Xu et al (2016) & $\begin{array}{l}\text { In vivo and } \\
\text { in vitro }\end{array}$ & $\begin{array}{l}\text { Human } \\
\text { breast ADSC }\end{array}$ & $\begin{array}{l}\text { A combination of G-Rg1 and PRF augments the effect } \\
\text { of neovascularization and adipogenesis compared } \\
\text { to G-Rg1 or PRF alone. }\end{array}$ & (84) \\
\hline Raafat et al (2018) & In vivo & Bone formation & $\begin{array}{l}\text { Statins loaded on PRF promote better bone healing and } \\
\text { bone maturation than each material alone. }\end{array}$ & (85) \\
\hline
\end{tabular}

biomaterial serves a role during proliferation and matrix generation, which may reduce the formation of disoriented connective tissue. Biocompatible membranes adsorbed with PRP and chitosan have excellent wound-healing effects (47). The composite scaffolds control the release of cytokines and enhance the proliferation of stem cells compared with platelet concentrates alone.

Furthermore, chitosan may be made porous and stabilized by different treatments, yielding improved properties that may then be combined with platelet concentrates (48). Lyophilized platelet concentrates are more rapidly combined with biomaterials when compared with fresh ones. By loading the lyophilized platelet concentrates on the chitosan membrane, the physical properties may be tuned; two primary advantages have been described $(49,50)$. First, the degradation rate is slow, which ensures a steady and prolonged release of
GF. Furthermore, their enhanced mechanical strength makes them more suitable for surgery. Combination with absorbable biomaterials, such as chitosan, provides a feasible approach to prepare wound dressings. The synthetic membrane may be designed to not only provide adequate mechanical strength for surgery but also delay the release of GF in platelet concentrates, matching the speed of tissue regeneration.

Silk fibroin. Silk fibroin offers good biocompatibility, slow degradation and excellent mechanical properties (51-53). When tissue defects are too large, platelet concentrates filling the defects may not be sufficient and in such cases, the combination of silk fibroin and PRF is a potentially suitable option (54). Owing to the excellent biocompatibility of silk fibrin, tissue regeneration may be accelerated by such synthetic biomaterials. However, slow degradation may induce immunoreaction and has an adverse impact on bone formation, as the 
scaffolds would occupy the space for bone formation. Thus, it is necessary to further explore the relationship between biodegradability and osteo-induction and calibrate the degradation rates of scaffolds for optimal bone formation.

Metal nanoparticles. Metal-derived nanoparticles are biocompatible, multifunctional and versatile materials, which are widely used as diagnostic and drug delivery tools in anticancer and antibacterial therapy (55). In the majority of cases, platelet concentrates are exposed to the oral cavity, where a large number of microorganisms may interfere with the treatment (56). Silver nanoparticles (SNP) have both high biocompatibility and antimicrobial properties. Preparation of platelet concentrates with the addition of SNP improved both the antibacterial abilities, primarily via the inhibition of viridans streptococci, and enhanced mechanical strength (57). A range of metal particles are being applied in medical research for different purposes and these nanoscale particles may endow platelet concentrates with novel biological properties (57). Appropriate nanoalloy particles not only improve the properties of platelet concentrates but also broaden the scope of clinical application.

Mineral trioxide aggregate (MTA). MTA is widely used in endodontic applications, including pulp capping, root perforation repair and root-end filling, to induce pulp regeneration and facilitate dentin bridge formation without causing inflammation. In 2016, Woo et al (58) aimed to evaluate the effect of combined MTA and PRF on odontoblastic differentiation in human dental pulp cells (h-DPC). Indeed, the combination exhibited a synergistic effect by accelerating differentiation via activation of the bone morphogenetic protein (BMP)/Smad signaling pathway. Since both materials promote pulp and dentin regeneration, their combination may represent a novel therapeutic strategy in the context of pulpitis.

Graft materials. Graft materials are frequently employed to improve bone volumes for dental surgery, such as autografts, allografts, xenografts and alloplastic grafts. However, the effects of grafts on osteogenesis may be limited without the assistance of autologous bioactive ingredients. Of note, platelet concentrates may help overcome these issues. The bone regeneration capacity of PRF mixed with $\beta$-tricalcium phosphate is higher than that of PRF alone, although the difference is only significant in the initial two weeks post-surgery (59). Furthermore, there are discrepancies regarding the effects of PRF combined with different grafts on bone formation and maturation (60). Autograft-PRF exhibits outstanding results in the formation of new bone when compared with any other combinations and the xenograft-PRF combination is also promising for such applications (60). This may be ascribed to the abundance of bioactive BMSC in autografts, which may cooperate with platelet concentrates to actively regenerate bone tissue. In addition, autografts may reduce immunological rejection compared to other types of grafts. In general, platelet concentrates provide a plethora of bioactive molecules, which may promote bone regeneration and deposition in graft materials $(59,60)$. Thus, the use of platelet concentrates for improving the effects of graft materials should be further studied.

Hydroxyapatite (HA). HA is a calcium phosphate compound that serves as a bone stuffer due to its mineral composition being similar to that of bone tissue. However, its use in surgery is limited owing to the challenge of handling HA at operation sites. Consequently, it is necessary to deliver HA granules using biomaterials. A liquid platelet concentrate may be appropriate for carrying HA granules (61). After thoroughly mixing the HA with platelet concentrates, the blend may be solidified prior to being implanted into tissue defects. On the other hand, fibrin glue and activated PRP loaded on composite scaffolds based on chitosan-gelatin/nanohydroxyapatite may improve osteogenic differentiation and proliferation of dental pulp stem cells (62). However, synthetic scaffolds offer certain advantages. First, platelets are typically scattered on the surface of the membrane, suggesting that the release of GF is smooth. In addition, the fibrin glue may guide the stem cells to adhere to the network structure and stimulate cells without further migration, which limits mesenchymal cell mobility. Finally, the scaffold provides a microenvironment rich in GF to promote differentiation and proliferation of stem cells. Both fibrin glue and PRP may promote the synthesis of the extracellular matrix.

\section{Platelet concentrates combined with stem cells}

Adipose-derived stem cells (ADSC). ADSC have a high potential to differentiate into several types of cells. In addition to their multipotent differentiation ability, the paracrine functions of ADSC also influence tissue regeneration (63). Certain studies suggested that the ability of ADSC to repair tissues originates from stimulating collagen synthesis, cellular matrix protein synthesis and dermis revascularization (64-66). The scaffolds and GF in platelet concentrates favor the proliferation of ADSC. It may thus be assumed that the combination of platelet concentrates and ADSC enhances tissue regeneration.

PRP functions co-operatively with conditioned medium obtained from adipose-derived MSC (ADMSC) to promote the proliferation and migration of fibroblasts and keratinocytes in vitro (66). It is assumed that PRP is able to interact with the conditioned medium from ADMSC to exert beneficial effects. However, although conditioned medium stimulates proliferation in a concentration-dependent manner, excessive PRP concentrations may have adverse effects on proliferation. This may be attributed to GF-inhibiting proteins within the complex mixture produced by platelets (such as platelet concentrates containing high levels of proteolytic enzymes inhibiting cell growth) (67-69). Furthermore, a deeper association between the activities of different cells was determined; a low concentration of PRP may promote the proliferation and migration of ADMSC and fibroblasts. In addition, the paracrine activity of ADMSC stimulates keratinocyte proliferation. Thus, there is a promising prospect for healing of cutaneous ulcers by exploiting the reparative synergy between ADMSC and PRP in the clinic.

It is particularly challenging to re-establish a sufficient blood supply after maxillofacial soft-tissue defects caused by irradiation. This leads to difficulties in recovering the damaged tissue to its pre-damaged condition both in terms of function and aesthetics. The abundance of GF in platelet concentrates and the multipotent differentiation potential and paracrine ability of ADSC provide an opportunity for healing this kind of tissue damage. A combination of platelet concentrates and stem cells induces adequate angiogenesis and reduces apoptotic activities (70). Acute myocardial infarction is another 
vital issue. Embedding ADMSC in the PRF scaffold was reported to improve acute myocardial infarction. An ADMSCembedded PRF scaffold preserved left ventricle thickness and function, ameliorated LV remodeling and inhibited inflammatory reactions and oxidative stress in a rat model (71). This improvement may be due to three reasons: First, PRF scaffolds provide a suitable environment for ADMSC to survive for a longer period; furthermore, the ADMSC-embedded PRF scaffold may induce the formation of more abundant vessels than direct ADMSC implantation alone; finally, implanting a PRF scaffold on the infarcted LV surface provides mechanical support and limits LV dilatation, thereby preserving the cardiac function to a certain extent.

$B M S C$. BMSC serve important roles in osteogenesis. It is possible to combine BMSC with platelet concentrates to produce bone tissue. The combined autologous BMSC and PRP may promote structural allogenic bone graft healing in a rabbit bone defect model. Abundant bridging trabeculae and increased expression of relevant osteoblastic proteins were determined in BMSC and PRP, suggesting the effectiveness of this combination (68). In 2017, Wang et al (72) also demonstrated that therapeutic application of MSC in isolation induces a lesser degree of central bone regeneration in bone defects when compared to combination treatment with both MSC and PRF. In the future, this cotreatment may improve clinical outcomes in patients receiving structural allografts. Periodontitis, a widespread chronic disease, destroys both soft and hard tissues. With traditional treatment, it is hard to regenerate the complete periodontium, including periodontal ligament (PDL), cementum and alveolar bone. Loading the PDL and jaw bone MSC sheets on PRF to restore periodontal defects is a novel approach (73). The two above-mentioned stem-cell types were used to form cell sheets that were able to differentiate into PDL- and bone-like tissues, respectively. Furthermore, PRF was used as a 3-dimensional fibrin network to support, sustain and nourish the cell sheets in the space between the simulated root surface and alveolar bone. After the implantation, PDL and bone-like structures were successfully induced in corresponding sites. It is not easy for articular cartilage to regenerate after injuries, even though progenitor cells are present in the superficial zone. Though autologous chondrocyte implantation is an established strategy for repairing cartilage injuries, there is a chance that fibrocartilage may form. In addition, pure BMSC injection leads to a small proportion of stem cells attaching to the defect sites to repair the injured cartilage, which may lead to unsatisfactory cartilage restoration. However, BMSC injection combined with PRF releasates offers improved results (74). PRF releasates may increase the thickness of the regenerated cartilage and improve the histological morphology, which may be ascribed to the roles of GF. Thus, the combination of PRF releasates and BMSC highlights an alternative strategy for autologous chondrocyte implantation to cure cartilage defects.

Stem-cell treatment has gained popularity in recent years. It is a feasible means of combining stem-cell treatment with platelet concentrates, as the platelet concentrates provide scaffolds for cells to adhere to and migrate from and the GF may promote stem-cell proliferation $(67,68,70-74)$. In addition, the activities of different types of cells may synergistically interact to produce beneficial outcomes.
$h$-DPC. Dental pulp regeneration is an important aspect of recovery from pulpitis and periapical disease. Therapeutic assistance, aimed at facilitating such regeneration, currently involves the use of differentiated cells, biological scaffolds and GF. There is an urgent requirement to develop more appropriate biocompatible scaffolds. Addition of an h-DPC suspension to blood prior to centrifugation during PRF preparation may be a feasible approach (75). This method distributes h-DPC to the buffy coat along with leukocytes, preserving h-DPC viability. This is because h-DPC are naturally occurring human cells, such as leukocytes. The reviewed study provides a novel method for preparing a combination cell-PRF complex, which may be generalizable to the incorporation of other stem cell types (such as BMSC) (75).

\section{Combination of platelet concentrates with drugs}

Antagonism. Certain medications used during the treatment process may cause adverse effects. For instance, bisphosphonates are used to manage osteoclast-mediated osseous resorption. However, long-term administration of bisphosphonates may result in a rare but adverse complication, namely osteonecrosis of the maxillary and mandibular bones (76-78). This side-effect may be ascribed to cytotoxic effects on osteoblasts, which may prevent cells from proliferating, adhering and migrating $(79,80)$. Owing to the impact of GF in platelet concentrates in terms of promoting the settlement, adhesion, proliferation and migration of osteoblasts, Steller et al (81) combined bisphosphonates with platelet concentrates to preserve the activity of osteoblasts. Different types of platelet concentrates may be able to inhibit bisphosphonates on different levels. However, PRF may have advantages over PRP in promoting stem-cell proliferation. This discrepancy may be due to two reasons. First, the release of GF from PRP occurs more rapidly than that of PRF due to the natural scaffold in PRF. Furthermore, a higher concentration of leukocytes in PRF may positively influence cell proliferation and migration, although the function of leukocytes is disputed (81). The plant-derived stilbenoid resveratrol has anti-inflammatory, antioxidant and bone-protective properties (82). In addition, it may enhance the therapeutic outcomes of CGF treatment in bisphosphonate-related osteonecrosis of the jaw (83). In particular, resveratrol may modulate the effects of CGF to protect osteoblasts. However, the influence of resveratrol on CGF against bisphosphonate-induced osteonecrosis is not always synergistic, as the outcome is dependent on experimental conditions.

Synergism. As mentioned above, engineered adipose tissues have recently gained popularity for use in reconstruction of soft-tissue defects. However, adipocytes are fragile and it is difficult to preserve them after grafting due to an inadequate blood supply. Ginsenoside Rg1 (G-Rg1) and PRF have been used to pretreat human breast adipose-derived stem cells (HBASC) prior to being seeded in a 3-dimensional porous sponge scaffold of collagen type I (84). G-Rg1 and PRF may induce the expression of angiogenic factors and G-Rg1 may increase the paracrine activity of HBASCs. Therefore, it is reasonable that the combination of G-Rg1 and PRF may result in the production of more adipose tissue than that produced by any material alone. Statins may increase BMP-2 expression directly to promote bone formation and may modulate the 
activities of osteoclasts and osteoblasts. PRF, an autologous fibrin scaffold, may not only serve as a carrier for statins, but also enhances bone formation due to its biological properties (85). The combination of PRF and statins provides superior osteosis, upregulation of both BMP-2 and VEGF protein and elevated bone anabolic serum markers as compared with those in samples treated with simvastatin or PRF separately.

Reasonable combinations of platelet concentrates with drugs may reduce side effects and enhance the effects of drugs due to the mutual effects between drugs and cytokines in platelet concentrates $(81,83-85)$. Furthermore, the fibrin matrix scaffold may serve as carriers for drugs in the target location. Thus, it is recommended to implement a combination of platelet concentrates and drugs to solve clinical issues.

\section{Conclusions}

Autologous platelet-derived concentrates are biocompatible products containing cytokines, platelets, leukocytes and fibrin, and may be regarded as a slow-release system, which ensures sustained delivery of active principles and GF for $\sim 2$ weeks. Of note, the release kinetics may influence the entire process of tissue regeneration. However, certain problems remain that must be addressed to optimize the formulation intended for tissue regeneration. The present review provided numerous novel applications of platelet concentrates for a wide range of tissue regeneration applications. Such applications aim to meet the demands for treatments and overcome the shortcomings of platelet concentrates. The freeze-drying method is an effective method for preserving the viability of platelet concentrates for comparatively longer periods, without any concerns regarding the loss of their effects in tissue regeneration. Combination with biomaterials, such as chitosan and silk fibrin, may enhance physical strength, making it suitable for suture in surgery. The synergistic effects of platelet concentrates and bone regenerative materials, including HA and graft materials, may induce rapid bone regeneration in diseases associated with bone loss, such as periodontitis and bone defects caused by tumors, amongst others. The addition of stem cells provides a novel approach for the rehabilitation of tissue morphology. Particularly in the skin and cartilage, it is necessary to restore the defective tissue to normal levels, which is important for aesthetics and normal function. Due to the complexity of clinical issues, tissue defects associated with infection and tissue damage caused by side effects of drugs are common in the clinic. Nanometal particles, such as nano-silver, have significant anti-bacterial properties. Combination of nano-silver and platelet concentrates provides integrated methods to inhibit bacteria and promote tissue regeneration for patients with burn damage. The antagonism of platelet concentrates to osteonecrosis induced by long-term administration of bisphosphonates provides a suitable method for curing patients with osteonecrosis. The efficacy and suitability of these creative approaches require to be further verified in clinical trials. Certain limitations remain in the field of tissue regeneration using platelet concentrations as follows: i) No studies are currently available on the application of modified methods using platelet concentrates, to the best of our knowledge, and thus, modified methods that may be used in the clinic were not reviewed; ii) particularly the underlying mechanisms remain elusive. In the future, studies on the detailed mechanisms of modification should be performed and evaluation of these experimental methods in the clinic should be performed. The use of platelet concentrates has demonstrated positive clinical effects in several fields of regenerative medicine. Simple administration of platelet concentrates cannot always meet the complex demands of clinical issues. Furthermore, different types of tissue have different healing periods. Future studies focusing on the methods of establishment of platelet concentrates as a multifunctional medical procedure, meeting the complex clinical issues, are thus required. In addition, the properties of platelet concentrates are important for clinical use, such as the ability to tightly bind with the tissue-surrounding defects and strong resilience, avoiding disruption. Thus, additional studies on modified strategies using platelet concentrates and prospects for clinical use are required.

\section{Acknowledgements}

Not applicable.

\section{Funding}

The present review was supported by a grant from the Natural Science Foundation of Hunan Province (project no. 2018JJ2546).

\section{Availability of data and materials}

Not applicable.

\section{Authors' contributions}

ZYD performed the primary literature searches and prepared the manuscript. QP, NL, JZ and YT read, edited and reviewed the manuscript. NL and JZ confirmed the authenticity of the raw data. All authors read and approved the final manuscript.

\section{Ethics approval and consent to participate}

Not applicable.

\section{Patient consent for publication}

Not applicable.

\section{Competing interests}

The authors declare that they have no competing interests.

\section{References}

1. Bishop CJ, Kim J and Green JJ: Biomolecule delivery to engineer the cellular microenvironment for regenerative medicine. Ann Biomed Eng 42: 1557-1572, 2014.

2. Abou Neel EA, Chrzanowski W, Salih VM, Kim HW and Knowles JC: Tissue engineering in dentistry. J Dent 42: 915-928, 2014.

3. Miron RJ and Zhang Y: Autologous liquid platelet rich fibrin: A novel drug delivery system. Acta Biomater 75: 35-51, 2018.

4. Kobayashi E, Flüickiger L, Fujioka-Kobayashi M, Sawada K, Sculean A, Schaller B and Miron RJ: Comparative release of growth factors from PRP, PRF, and advanced-PRF. Clin Oral Investig 20: 2353-2360, 2016 
5. Miron RJ, Fujioka-Kobayashi M, Bishara M, Zhang Y, Hernandez $M$ and Choukroun J: Platelet-rich fibrin and soft tissue wound healing: A systematic review. Tissue Eng Part B Rev 23: 83-99, 2017.

6. Alsousou J, Ali A, Willett $\mathrm{K}$ and Harrison P: The role of platelet-rich plasma in tissue regeneration. Platelets 24: 173-182, 2013.

7. Görmeli G, Görmeli CA, Ataoglu B, Çolak C, Aslantürk O and Ertem K: Multiple PRP injections are more effective than single injections and hyaluronic acid in knees with early osteoarthritis: A randomized, double-blind, placebo-controlled trial. Knee Surg Sports Traumatol Arthrosc 25: 958-965, 2017.

8. Huang Y, Liu X, Xu X and Liu J: Intra-articular injections of platelet-rich plasma, hyaluronic acid or corticosteroids for knee osteoarthritis: A prospective randomized controlled study. Orthopade 48: 239-247, 2019.

9. Bhujbal R, A Malik N, Kumar N, Kv S, I Parkar M and Mb J: Comparative evaluation of platelet rich plasma in socket healing and bone regeneration after surgical removal of impacted mandibular third molars. J Dent Res Dent Clin Dent Prospect 12: 153-158, 2018.

10. Del Fabbro M, Bucchi C, Lolato A, Corbella S, Testori T and Taschieri S: Healing of postextraction sockets preserved with autologous platelet concentrates. A systematic review and meta-analysis. J Oral Maxillofac Surg 75: 1601-1615, 2017.

11. Alio JL, Rodriguez AE, De Arriba P, Gisbert S and Abdelghany AA Treatment with platelet-rich plasma of surgically related dormant corneal ulcers. Eur J Ophthalmol 28: 515-520, 2018.

12. Tambella AM, Attili AR, Dini F, Palumbo Piccionello A, Vullo C, Serri E, Scrollavezza P and Dupré G: Autologous platelet gel to treat chronic decubital ulcers: A randomized, blind controlled clinical trial in dogs. Vet Surg 43: 726-733, 2014.

13. Tambella AM, Attili AR, Dupré G, Cantalamessa A, Martin S, Cuteri V, Marcazzan S and Del Fabbro M: Platelet-rich plasma to treat experimentally-induced skin wounds in animals: A systematic review and meta-analysis. PLoS One 13: e0191093, 2018.

14. Burgos-Alonso, N., Lobato I, Hernández I, San Sebastian K, RodríguezB, March AG,Perez-Salvador A,Arce V,Garcia-AlvarezA, Gomez-Fernandez MC, et al: Autologous platelet-rich plasma in the treatment of venous leg ulcers in primary care: A randomised controlled, pilot study. J Wound Care 27 (Suppl 6): S20-S24.

15. Martinez-Zapata MJ, Martí-Carvajal AJ, Solà I, Expósito JA, Bolíbar I, Rodríguez L, Garcia J and Zaror C: Autologous platelet-rich plasma for treating chronic wounds. Cochrane Database Syst Rev: May 25, 2016. doi: 10.1002/14651858.CD006899.pub3.

16. Moneib HA, Youssef SS, Aly DG, Rizk MA and Abdelhakeem YI: Autologous platelet-rich plasma versus conventional therapy for the treatment of chronic venous leg ulcers: A comparative study. J Cosmet Dermatol 17: 495-501, 2018.

17. Picard F, Hersant B, Bosc R and Meningaud JP: The growing evidence for the use of platelet-rich plasma on diabetic chronic wounds: A review and a proposal for a new standard care. Wound Repair Regen 23: 638-643, 2015.

18. Masoudi E, Ribas J, Kaushik G, Leijten J and Khademhosseini A Platelet-rich blood derivatives for stem cell-based tissue engineering and regeneration. Curr Stem Cell Rep 2: 33-42, 2016.

19. Hatakeyama I, Marukawa E, Takahashi Y and Omura K: Effects of platelet-poor plasma, platelet-rich plasma, and platelet-rich fibrin on healing of extraction sockets with buccal dehiscence in dogs. Tissue Eng Part A 20: 874-882, 2014

20. Anitua E, Nurden P, Prado R, Nurden AT and Padilla S: Autologous fibrin scaffolds: When platelet- and plasma-derived biomolecules meet fibrin. Biomaterials 192: 440-460, 2019.

21. Dohan DM, Choukroun J, Diss A, Dohan SL, Dohan AJ, Mouhyi J and Gogly B: Platelet-rich fibrin (PRF): A second-generation platelet concentrate. Part II: platelet-related biologic features. Oral Surg Oral Med Oral Pathol Oral Radiol Endod 101: e45-e50, 2006

22. Shah R, M G T, Thomas R and Mehta DS: An Update on the protocols and biologic actions of platelet rich fibrin in dentistry. Eur J Prosthodont Restor Dent 25: 64-72, 2017.

23. Ghanaati S, Booms P, Orlowska A, Kubesch A, Lorenz J, Rutkowski J, Landes C, Sader R, Kirkpatrick C and Choukroun J: Advanced platelet-rich fibrin: A new concept for cell-based tissue engineering by means of inflammatory cells. J Oral Implantol 40 : 679-689, 2014

24. Wend S, Kubesch A, Orlowska A, Al-Maawi S, Zender N, Dias A Miron RJ, Sader R, Booms P, Kirkpatrick CJ, et al: Reduction of the relative centrifugal force influences cell number and growth factor release within injectable PRF-based matrices. J Mater Sci Mater Med 28: 188, 2017.
25. Pitzurra L, Jansen IDC, de Vries TJ, Hoogenkamp MA and Loos BG: Effects of L-PRF and A-PRF ${ }^{+}$on periodontal fibroblasts in in vitro wound healing experiments. J Periodontal Res 55: 287-295, 2020

26. Miron RJ, Fujioka-Kobayashi M, Hernandez M, Kandalam U, Zhang Y, Ghanaati S and Choukroun J: Injectable platelet rich fibrin (i-PRF): Opportunities in regenerative dentistry? Clin Oral Investig 21: 2619-2627, 2017.

27. Malli Sureshbabu N, Selvarasu K, v JK, Nandakumar M and Selvam D: Concentrated growth factors as an ingenious biomaterial in regeneration of bony defects after periapical surgery: A report of two cases. Case Rep Dent 2019: 7046203, 2019.

28. Dohan Ehrenfest DM, Rasmusson L and Albrektsson T: Classification of platelet concentrates: From pure platelet-rich plasma (P-PRP) to leucocyte- and platelet-rich fibrin (L-PRF). Trends Biotechnol 27: 158-167, 2009.

29. Boateng JS, Matthews KH, Stevens HN and Eccleston GM: Wound healing dressings and drug delivery systems: A review. J Pharm Sci 97: 2892-2923, 2008.

30. Broughton G II, Janis JE and Attinger CE: The basic science of wound healing. Plast Reconstr Surg 117 (Suppl 7): 12S-34S, 2006.

31. Etulain J: Platelets in wound healing and regenerative medicine. Platelets 29: 556-568, 2018.

32. Walsh TG, Metharom P and Berndt MC: The functional role of platelets in the regulation of angiogenesis. Platelets 26: 199-211, 2015

33. Pierce GF, Mustoe TA, Altrock BW, Deuel TF and Thomason A Role of platelet-derived growth factor in wound healing. J Cell Biochem 45: 319-326, 1991.

34. Briquez PS, Hubbell JA and Martino MM: Extracellular matrix-inspired growth factor delivery systems for skin wound healing. Adv Wound Care (New Rochelle) 4: 479-489, 2015.

35. Martino MM, Brkic S, Bovo E, Burger M, Schaefer DJ, Wolff T, Gürke L, Briquez PS, Larsson HM, Gianni-Barrera R, et al: Extracellular matrix and growth factor engineering for controlled angiogenesis in regenerative medicine. Front Bioeng Biotechnol 3: 45, 2015.

36. Janmey PA, Winer JP and Weisel JW: Fibrin gels and their clinical and bioengineering applications. J R Soc Interface 6: 1-10, 2009.

37. Sánchez M, Anitua E, Delgado D, Prado R, Sánchez P, Fiz N, Guadilla J, Azofra J, Pompei O, Orive G, et al: Ultrasound-guided plasma rich in growth factors injections and scaffolds hasten motor nerve functional recovery in an ovine model of nerve crush injury. J Tissue Eng Regen Med 11: 1619-1629, 2017.

38. Haugh MG, Murphy CM and O'Brien FJ: Novel freeze-drying methods to produce a range of collagen-glycosaminoglycan scaffolds with tailored mean pore sizes. Tissue Eng Part C Methods 16: 887-894, 2010

39. Roy I and Gupta MN: Freeze-drying of proteins: Some emerging concerns. Biotechnol Appl Biochem 39: 165-177, 2004.

40. Shi L, Li R, Wei S, Zhou M, Li L, Lin F, Li Y, Guo Z, Zhang W, Chen $\mathrm{M}$, et al: Effects of a protective agent on freeze-dried platelet-rich plasma. Blood Coagul Fibrinolysis 30: 58-65, 2019.

41. Wang Z, Han L, Sun T, Wang W, Li X and Wu B: Preparation and effect of lyophilized platelet-rich fibrin on the osteogenic potential of bone marrow mesenchymal stem cells in vitro and in vivo. Heliyon 5: e02739, 2019.

42. Li Q, Reed DA, Min L, Gopinathan G, Li S, Dangaria SJ, Li L, Geng Y, Galang MT, Gajendrareddy P, et al: Lyophilized platelet-rich fibrin (PRF) promotes craniofacial bone regeneration through Runx2. Int J Mol Sci 15: 8509-8525, 2014.

43. Zhang J, Qi X, Luo X, Li D, Wang H and Li T: Clinical and immunohistochemical performance of lyophilized platelet-rich fibrin (Ly-PRF) on tissue regeneration. Clin Implant Dent Relat Res 19: 466-477, 2017.

44. Liu Z, Jin H, Xie Q, Jiang Z, Guo S, Li Y and Zhang B: Controlled release strategies for the combination of fresh and lyophilized platelet-rich fibrin on bone tissue regeneration. BioMed Res Int 2019: 4923767, 2019.

45. Sam G, Vadakkekuttical RJ and Amol NV: In vitro evaluation of mechanical properties of platelet-rich fibrin membrane and scanning electron microscopic examination of its surface characteristics. J Indian Soc Periodontol 19: 32-36, 2015.

46. Behera SS, Das U, Kumar A, Bissoyi A and Singh AK: Chitosan/TiO2 composite membrane improves proliferation and survival of L929 fibroblast cells: Application in wound dressing and skin regeneration. Int J Biol Macromol 98: 329-340, 2017.

47. Mohammadi R, Mehrtash M, Mehrtash M, Hassani N and Hassanpour A: Effect of platelet rich plasma combined with chitosan biodegradable film on full-thickness wound healing in rat model. Bull Emerg Trauma 4: 29-37, 2016. 
48. Shimojo AA, Perez AG, Galdames SE, Brissac IC and Santana MH: Stabilization of porous chitosan improves the performance of its association with platelet-rich plasma as a composite scaffold. Mater Sci Eng C 60: 538-546, 2016.

49. Wang L, Wan M, Li Z, Zhong N, Liang D and Ge L: A comparative study of the effects of concentrated growth factors in two different forms on osteogenesis in vitro. Mol Med Rep 20: 1039-1048, 2019

50. Ansarizadeh M, Mashayekhan S and Saadatmand M: Fabrication, modeling and optimization of lyophilized advanced platelet rich fibrin in combination with collagen-chitosan as a guided bone regeneration membrane. Int J Biol Macromol 125: 383-391, 2019.

51. Dal Pra I, Freddi G, Minic J, Chiarini A and Armato U: De novo engineering of reticular connective tissue in vivo by silk fibroin nonwoven materials. Biomaterials 26: 1987-1999, 2005.

52. Horan RL, Antle K, Collette AL, Wang Y, Huang J, Moreau JE, Volloch V, Kaplan DL and Altman GH: In vitro degradation of silk fibroin. Biomaterials 26: 3385-3393, 2005.

53. Franco AR, Fernandes EM, Rodrigues MT, Rodrigues FJ, Gomes ME, Leonor IB, Kaplan DL and Reis RL: Antimicrobial coating of spider silk to prevent bacterial attachment on silk surgical sutures. Acta Biomater 99: 236-246, 2019.

54. Lee EH, Kim JY, Kweon HY, Jo YY, Min SK, Park YW, Choi JY and Kim SG: A combination graft of low-molecular-weight silk fibroin with Choukroun platelet-rich fibrin for rabbit calvarial defect. Oral Surg Oral Med Oral Pathol Oral Radiol Endod 109: e33-e38, 2010.

55. Kuchur OA, Tsymbal SA, Shestovskaya MV, Serov NS, Dukhinova MS and Shtil AA: Metal-derived nanoparticles in tumor theranostics: Potential and limitations. J Inorg Biochem 209: 111117, 2020.

56. Zhang J, Xu Q, Huang C, Mo A, Li J and Zuo Y: Biological properties of an anti-bacterial membrane for guided bone regeneration: An experimental study in rats. Clin Oral Implants Res 21: 321-327, 2010.

57. Khorshidi H,Haddadi P, Raoofi S, Badiee Pand Dehghani Nazhvani A: Does adding silver nanoparticles to leukocyte- and platelet-rich fibrin improve its properties? BioMed Res Int 2018: 8515829, 2018

58. Woo SM, Kim WJ, Lim HS, Choi NK, Kim SH, Kim SM and Jung JY: Combination of mineral trioxide aggregate and platelet-rich fibrin promotes the odontoblastic differentiation and mineralization of human dental pulp cells via BMP/Smad signaling pathway. J Endod 42: 82-88, 2016.

59. Abdullah WA: Evaluation of bone regenerative capacity in rats claverial bone defect using platelet rich fibrin with and without beta tri calcium phosphate bone graft material. Saudi Dent J 28: 109-117, 2016.

60. Karayürek F, Kadiroğlu ET, Nergiz Y, Coşkun Akçay N, Tunik S, Ersöz Kanay B and Uysal E: Combining platelet rich fibrin with different bone graft materials: An experimental study on the histopathological and immunohistochemical aspects of bone healing. J Craniomaxillofac Surg 47: 815-825, 2019.

61. Ohba S, Wang W, Itoh S, Takagi Y, Nagai A and Yamashita K Acceleration of new bone formation by an electrically polarized hydroxyapatite microgranule/platelet-rich plasma composite. Acta Biomater 8: 2778-2787, 2012.

62. Sadeghinia A, Davaran S, Salehi R and Jamalpoor Z: Nano-hydroxy apatite/chitosan/gelatin scaffolds enriched by a combination of platelet-rich plasma and fibrin glue enhance proliferation and differentiation of seeded human dental pulp stem cells. Biomed Pharmacother 109: 1924-1931, 2019.

63. Suga H, Glotzbach JP, Sorkin M, Longaker MT and Gurtner GC Paracrine mechanism of angiogenesis in adipose-derived stem cell transplantation. Ann Plast Surg 72: 234-241, 2014.

64. Klar AS, Güven S, Zimoch J, Zapiórkowska NA, Biedermann T, Böttcher-Haberzeth S, Meuli-Simmen C, Martin I, Scherberich A, Reichmann E, et al: Characterization of vasculogenic potential of human adipose-derived endothelial cells in a three-dimensional vascularized skin substitute. Pediatr Surg Int 32: 17-27, 2016

65. Lee SH, Jin SY, Song JS, Seo KK and Cho KH: Paracrine effects of adipose-derived stem cells on keratinocytes and dermal fibroblasts. Ann Dermatol 24: 136-143, 2012.

66. Moon KM, Park YH, Lee JS, Chae YB, Kim MM, Kim DS Kim BW, Nam SW and Lee JH: The effect of secretory factors of adipose-derived stem cells on human keratinocytes. Int J Mol Sci 13: 1239-1257, 2012.

67. Stessuk T, Puzzi MB, Chaim EA, Alves PC, de Paula EV, Forte A, Izumizawa JM, Oliveira CC, Frei F and Ribeiro-Paes JT: Platelet-rich plasma (PRP) and adipose-derived mesenchymal stem cells: Stimulatory effects on proliferation and migration of fibroblasts and keratinocytes in vitro. Arch Dermatol Res 308: 511-520, 2016.

68. Park CG, Joo MW, Jeong J, Kang YK and Lee DR: Evaluation of the effects of the combination of autologous mesenchymal stem cells and platelet-rich plasma on structural bone allograft healing. Cell Tissue Bank 18: 229-238, 2017.
69. Mills DC, Robb IA and Roberts GC: The release of nucleotides, 5-hydroxytryptamine and enzymes from human blood platelets during aggregation. J Physiol 195: 715-729, 1968.

70. Chen Y, Niu Z, Xue Y, Yuan F, Fu Y and Bai N: Improvement in the repair of defects in maxillofacial soft tissue in irradiated minipigs by a mixture of adipose-derived stem cells and platelet-rich fibrin. Br J Oral Maxillofac Surg 52: 740-745, 2014.

71. Sun CK, Zhen YY, Leu S, Tsai TH, Chang LT, Sheu JJ, Chen YL, Chua S, Chai HT, Lu HI, et al: Direct implantation versus platelet-rich fibrin-embedded adipose-derived mesenchymal stem cells in treating rat acute myocardial infarction. Int J Cardiol 173: 410-423, 2014

72. Wang X, Li G, Guo J, Yang L, Liu Y, Sun Q, Li R and Yu W: Hybrid composites of mesenchymal stem cell sheets, hydroxyapatite, and platelet-rich fibrin granules for bone regeneration in a rabbit calvarial critical-size defect model. Exp Ther Med 13: 1891-1899, 2017.

73. Wang ZS, Feng ZH, Wu GF, Bai SZ, Dong Y, Chen FM and Zhao YM: The use of platelet-rich fibrin combined with periodontal ligament and jaw bone mesenchymal stem cell sheets for periodontal tissue engineering. Sci Rep 6: 28126, 2016.

74. Wu CC, Sheu SY, Hsu LH, Yang KC, Tseng CC and Kuo TF: Intra-articular Injection of platelet-rich fibrin releasates in combination with bone marrow-derived mesenchymal stem cells in the treatment of articular cartilage defects: An in vivo study in rabbits. J Biomed Mater Res B Appl Biomater 105: 1536-1543, 2017.

75. He X, Chen WX, Ban G, Wei W, Zhou J, Chen WJ and Li XY: A new method to develop human dental pulp cells and platelet-rich fibrin complex. J Endod 42: 1633-1640, 2016.

76. Graves LL, Bukata SV, Aghazadehsanai N, Chang TI, Garrett NR and Friedlander AH: Patients receiving parenteral bisphosphonates for malignant disease and having developed an atypical femoral fracture are at risk of concomitant osteonecrosis of the jaw: an evidence-based review. J Oral Maxillofac Surg 74: 2403-2408, 2016.

77. Lundberg AP, Roady PJ, Somrak AJ, Howes ME and Fan TM: Zoledronate-associated osteonecrosis of the jaw in a dog with appendicular osteosarcoma. J Vet Intern Med 30: 1235-1240, 2016.

78. Kharazmi M, Hallberg P, Warfvinge G and Michaëlsson K: Risk of atypical femoral fractures and osteonecrosis of the jaw associated with alendronate use compared with other oral bisphosphonates. Rheumatology (Oxford) 53: 1911-1913, 2014.

79. Street J, Bao M, deGuzman L, Bunting S, Peale FV Jr, Ferrara N, Steinmetz H, Hoeffel J, Cleland JL, Daugherty A, et al: Vascular endothelial growth factor stimulates bone repair by promoting angiogenesis and bone turnover. Proc Natl Acad Sci USA 99: 9656-9661, 2002

80. KrügerTB,Herlofson BB,Landin MA and Reseland JE: Alendronate alters osteoblast activities. Acta Odontol Scand 74: 550-557, 2016.

81. Steller D, Herbst N, Pries R, Juhl D and Hakim SG: Positive impact of Platelet-rich plasma and Platelet-rich fibrin on viability, migration and proliferation of osteoblasts and fibroblasts treated with zoledronic acid. Sci Rep 9: 8310, 2019

82. Ginés C, Cuesta S, Kireev R, García C, Rancan L, Paredes SD, Vara E and Tresguerres JAF: Protective effect of resveratrol against inflammation, oxidative stress and apoptosis in pancreas of aged SAMP8 mice. Exp Gerontol 90: 61-70, 2017.

83. Borsani E, Bonazza V, Buffoli B, Nocini PF, Albanese M, Zotti F, Inchingolo F, Rezzani R and Rodella LF: Beneficial effects of concentrated growth factors and resveratrol on human osteoblasts in vitro treated with bisphosphonates. BioMed Res Int 2018: 4597321, 2018

84. Xu FT, Liang ZJ, Li HM, Peng QL, Huang MH, Li Q, Liang YD, Chi GY, Li H, Yu BC, et al: Ginsenoside Rgl and platelet-rich fibrin enhance human breast adipose-derived stem cell function for soft tissue regeneration. Oncotarget 7: 35390-35403, 2016.

85. Raafat SN, Amin RM, Elmazar MM, Khattab MM and El-Khatib AS: The sole and combined effect of simvastatin and platelet rich fibrin as a filling material in induced bone defect in tibia of albino rats. Bone 117: 60-69, 2018

86. Isobe $\mathrm{K}$, Watanebe $\mathrm{T}$, Kawabata $\mathrm{H}$, et al.: Mechanical and degradation properties of advanced platelet-rich fibrin (A-PRF), concentrated growth factors (CGF), and platelet-poor plasmaderived fibrin (PPTF). Int J Implant Dent 3: 17, 2017.

87. Masuki H, Okudera T, Watanebe T, et al.: Growth factor and proinflammatory cytokine contents in platelet-rich plasma (PRP), plasma rich in growth factors (PRGF), advanced platelet-rich fibrin (A-PRF), and concentrated growth factors (CGF). Int J Implant Dent 2, 2016.

This work is licensed under a Creative Commons Attribution-NonCommercial-NoDerivatives 4.0 International (CC BY-NC-ND 4.0) License. 